\title{
ASTRONOMICAL DISCOVERY
}



Astronomical

Discovery

\section{HERBERT HALL TURNER}

Foreword by Dirk Brouwer 
University of California Press

Berkeley and Los Angeles, California

Cambridge University Press

London, England

(C) 1963 by The Regents of the University of California

Library of Congress Catalog Card Number: 63-866I

Originally published by Edward Arnold Ltd., London, England, 1904

Manufactured in the United States of America 
ro

\section{EDWARD EMERSON BARNARD}

ASTRONOMICAL DISCOVERER

THESE PAGES ARE INSCRIBED IN MEMORY OF

NEVER-TO-BE-FORGOTTEN DAYS SPENT WITH HIM AT THE

YERKES OBSERVATORY

or

THE UNIVERSITY OF CHICAGO 
